\title{
Subcutaneous emphysema and pneumomediastinum complicating a dental procedure
}

\author{
Dental işlemin komplikasyonu olarak gelişen cilt altı amfizemi ve \\ pnömomediasten
}

\author{
İsa DÖNGEL, ${ }^{1}$ Mehmet BAYRAM, ${ }^{2}$ İsmail Önder UYSAL, ${ }^{3}$ Güven Sadi SUNAM ${ }^{4}$
}

Cervicofacial emphysema and pneumomediastinum are rarely observed complications of dental interventions. The complications are associated with the use of a high-speed air-turbine dental drill. It is a potentially life-threatening condition, but the majority of cases are self-limiting and benign. We describe a patient with remarkable subcutaneous emphysema, pneumomediastinum, and partial pneumothorax after right second mandibular molar extraction. Dentists and physicians more often attribute the rapid onset of dyspnea in patients after a dental procedure to an allergic reaction to the anesthesia used during the procedure. Dentists and physicians should be aware that soft tissue emphysema can cause acute swelling of the cervicofacial region after dental procedures, which may mimic an allergic reaction.

Key Words: Dental procedure; pneumomediastinum; subcutaneous emphysema.
Servikofasyal amfizem ve pnömomediasten dental girişimlerden sonra nadiren gelişen komplikasyonlardır ve yüksek hızlı hava türbinli dental matkap kullanımı ile ilişkilidir. Yaşamı tehdit etme potansiyeli olan bir durum olsa da olguların büyük çoğunluğunda kendini sınırlar ve tehlike oluşturmaz. Bu yazıda sağ alt ikinci molar diş çekimi sonrasında gözle görülür cilt altı amfizemi, pnömomediasten ve parsiyel pnömotoraks gelişen hasta sunuldu. Diş hekimleri ve hekimler dental işlemi takiben ani dispne gelişmesini daha çok kullanılan anesteziklere karşı alerjik reaksiyona bağlama eğilimindedirler. Diş hekimleri ve hekimler dental işlem sonrası alerjik reaksiyonu taklit eden cilt altı amfizemine bağlı servikofasyal bölgede yumuşak dokuda şişme olabileceği konusunda dikkatli olmalıdırlar.

Anahtar Sözcükler: Dental işlem; pnömomediasten; cilt altı amfizemi.
Cervicofacial emphysema and pneumomediastinum are rare complications of dental procedures. ${ }^{[1]}$ While mostly benign and self limiting, life-threatening conditions may occur if the complications go unrecognized. Unaware physicians may consider this entity as an allergic reaction.

We present a case of cervicofacial emphysema, pneumomediastinum and pneumothorax occurring in a 46-year-old female following the removal of the right second mandibular molar.

\section{CASE REPORT}

A 46-year-old female was referred to the emergency department with a history of central dyspnea, chest pain and bilateral cervical swelling. One hour before, she had undergone a lower right second molar surgical extraction under local anesthesia by a general dental practitioner. Her general condition was fine, with a pulse of $80 / \mathrm{min}$, blood pressure of $110 / 70 \mathrm{mmHg}$, respiratory rate of $16 / \mathrm{min}$, temperature of $36.8^{\circ} \mathrm{C}$, and maintaining oxygen saturation of $97 \%$. The examina-

\footnotetext{
Departments of ${ }^{1}$ Thoracic Surgery, ${ }^{2}$ Chest Disease, Sivas State Hospital,

Sivas; ${ }^{3}$ Department of Otorhinolaryngology, Cumhuriyet University

Faculty of Medicine, Sivas; ${ }^{4}$ Department of Thoracic Surgery, Selcuklu University Faculty of Medicine, Konya, Turkey.
}

Sivas Devlet Hastanesi, ${ }^{1}$ Göğüs Cerrahisi Kliniği, ${ }^{2}$ Göğüs Hastalıkları Kliniği, Sivas; ${ }^{3}$ Cumhuriyet Üniversitesi Tıp Fakültesi, KBB Hastalıkları Anabilim Dalı, Sivas; ${ }^{4}$ Selçuklu Üniversitesi Tıp Fakültesi, Göğüs Cerrahisi Anabilim Dalı, Konya. 
tion revealed bilateral neck swelling and trachea in midline, with crepitus on palpation, suggesting profound cutaneous emphysema. Her chest radiograph showed an extensive subcutaneous emphysema, pneumomediastinum and partial pneumothorax on the right side, as shown in Fig. 1.

A thorax catheter was inserted to the right hemithorax. $100 \%$ oxygen was supplied using a facemask for the first two days. The patient was also managed conservatively with intravenous antibiotics and analgesics. The cervicofacial swelling and crepitus subsided, and partial pneumothorax was resorbed within the next three days. Computerized tomography of the thorax showed the air through the tissue planes to the mediastinum and aortic arch and subcutaneous region (Figs. 2a, b) on the 5th day. The patient was discharged from the hospital in good condition.

\section{DISCUSSION}

Cervical emphysema and pneumomediastinum can be defined as the presence of air in subcutaneous soft tissue and mediastinum. This clinical condition is reported to be caused by a high-speed air-turbine dental drill or other pressured appliances used during dental procedures. ${ }^{[2,3]}$ These appliances can introduce the pressured air into the soft tissues. Especially in procedures involving the molar teeth, air can diffuse the pterygomandibular region and lateral pharyngeal spaces from the retromolar region. ${ }^{[4]}$ The presence of free air on the retropharyngeal space may lead to eustachian tube dysfunction and hearing loss, dysphonia and dysphagia. ${ }^{[5]}$ The roots of molar teeth are connected directly with the submandibular space, which communicates with the retropharyngeal space and mediastinum. Air can also reach the retroperitoneum and pleural cavity. It is reported that subcutaneous emphysema and pneumomediastinum can also be seen after

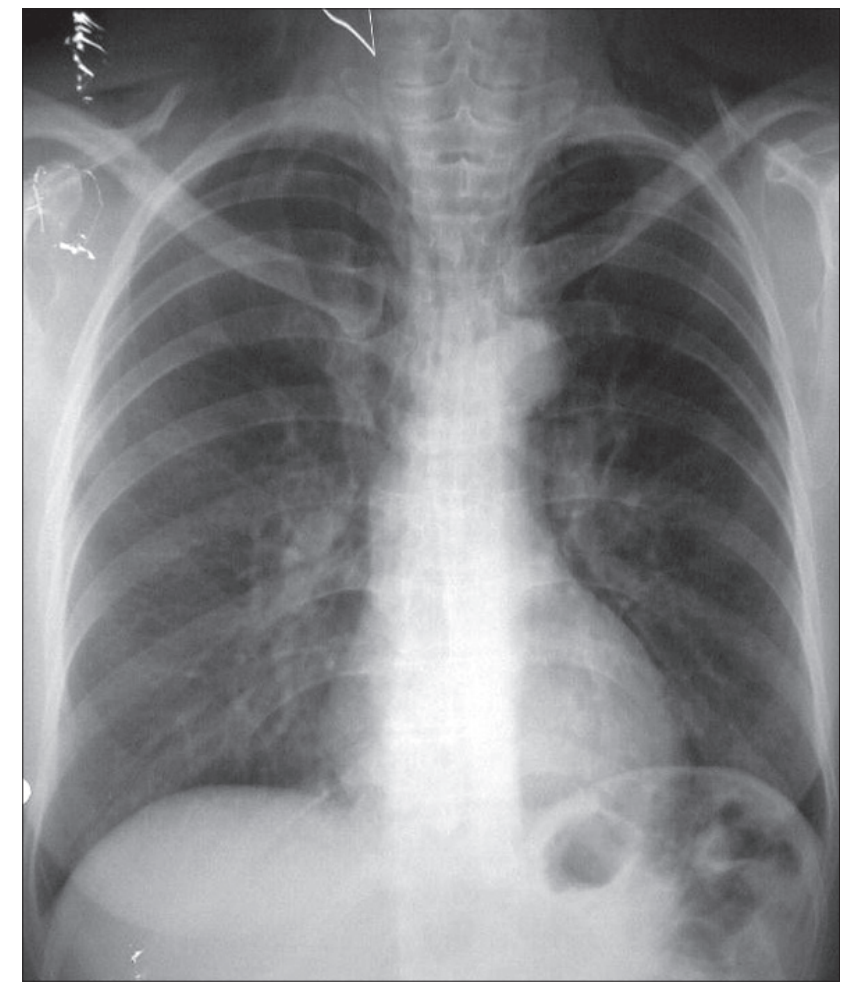

Fig. 1. Chest radiography showing pneumomediastinum and subcutaneous emphysema.

sneezing and nose blowing. ${ }^{[6]}$ Crepitus on palpation and tenderness are findings of cervical emphysema. Retrosternal pain and dyspnea are characteristic findings of pneumomediastinum. The sign of pneumomediastinum includes dull cardiac sound and mediastinal crepitation with systolic contraction heart (Hamman's sign). Venous distension, hypotension, hypercarbia, and acidosis are life-threatening consequences of massive air trapping in the mediastinum. Roentgenographic evidence of air within the mediastinum is diagnostic for this entity. Free air is readily seen as a thin line of
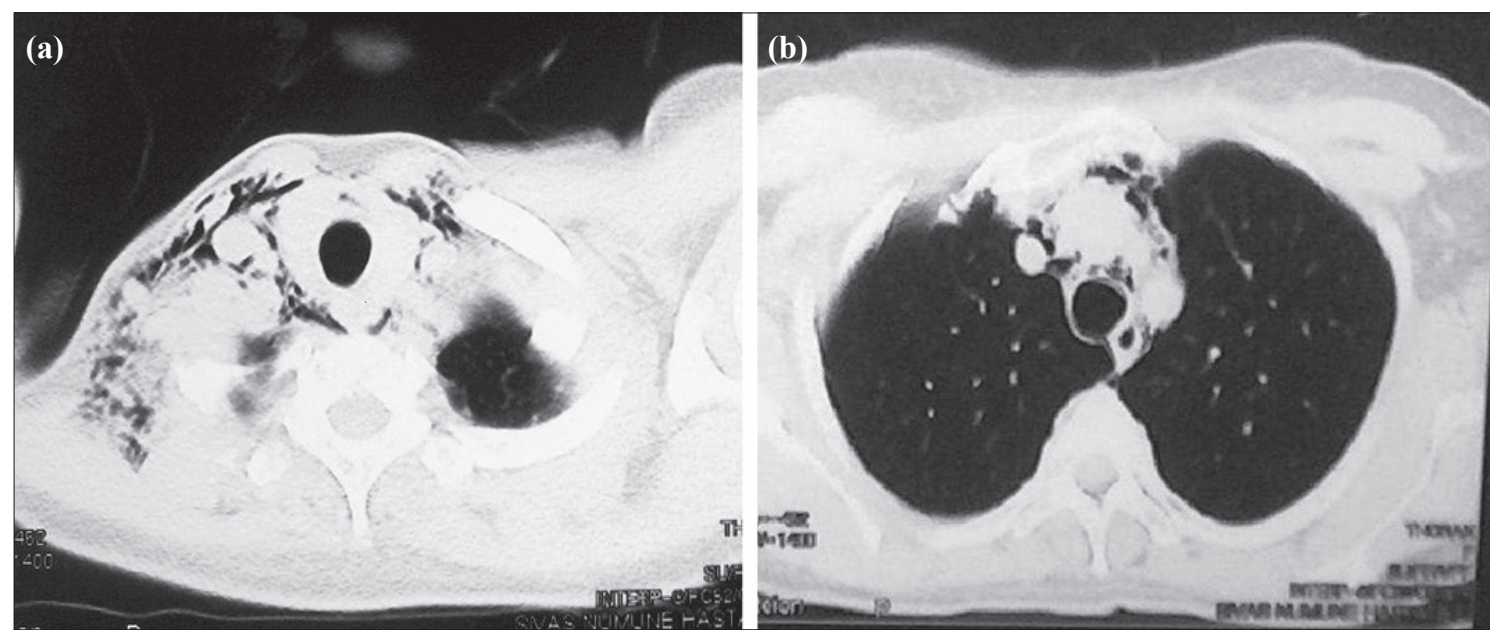

Fig. 2. (a) Axial computerized tomography of the thorax showing air in the mediastinum. (b) Axial computerized tomography of the thorax showing air within upper anterior chest wall. 
radiolucency outlining the cardiac border on posteroanterior chest radiography (Fig. 1). Treatment of pneumomediastinum and subcutaneous emphysema is usually conservative. Nitrogen washout with inhalation of $100 \%$ oxygen is suggested. Microorganisms of the oral cavity flora can easily migrate to the mediastinum and cause mediastinitis. ${ }^{[7]}$ In this case, broad-spectrum antibiotics be administered.

Antitussives and laxatives may be used to prevent air embolism due to high intrathoracic pressure. Most of the cervical emphysema and pneumomediastinum cases are benign and self-limiting. However, tracheal compression, pneumopericardium, tension pneumomediastinum, and cardiac tamponade are life-threatening complications. Infective mediastinitis and sepsis may also occur. Recognition of cervical emphysema and pneumomediastinum is easy; however, it is essential to be aware of this entity, which may occur after dental procedures. Otherwise, dentists and emergency physicians may misdiagnose the condition as an allergic reaction, hematoma or infection.

\section{REFERENCES}

1. Guest PG, Henderson S. Surgical emphysema of the mediastinum as a consequence of attempted extraction of a third molar tooth using an air turbine drill. Br Dent J 1991;171:283-4.

2. Monsour PA, Savage NW. Cervicofacial emphysema following dental procedures. Aust Dent J 1989;34:403-6.

3. Szubin L, La Bruna A, Levine J, Komisar A. Subcutaneous and retropharyngeal emphysema after dental procedures. Otolaryngol Head Neck Surg 1997;117:122-3.

4. Cardo VA Jr, Mooney JW, Stratigos GT. Iatrogenic dental-air emphysema: report of case. J Am Dent Assoc 1972;85:144-7.

5. Stillman PL, Ruggill JS, Rutala PJ, Dinham SM, Sabers DL. Students transferring into an American medical school. Remediating their deficiencies. JAMA 1980;243:129-33.

6. Damore DT, Dayan PS. Medical causes of pneumomediastinum in children. Clin Pediatr (Phila). 2001;40:87-91.

7. Reznick JB, Ardary WC. Cervicofacial subcutaneous air emphysema after dental extraction. J Am Dent Assoc 1990;120:417-9. 